\title{
Same-sex parenting and children's outcomes: A closer examination of the American Psychological Association's brief on lesbian and gay parenting
}

\section{Loren Marks}

Brigham Young University - Provo, loren_marks@byu.edu

Follow this and additional works at: https://scholarsarchive.byu.edu/facpub

Part of the Other Social and Behavioral Sciences Commons

\section{Original Publication Citation}

Marks, L. (2012). Same-sex parenting and children's outcomes: A closer examination of the American Psychological Association's Brief on Lesbian and Gay Parenting. Social Science Research, 41, 735-751.

\section{BYU ScholarsArchive Citation}

Marks, Loren, "Same-sex parenting and children's outcomes: A closer examination of the American Psychological Association's brief on lesbian and gay parenting" (2012). Faculty Publications. 4875. https://scholarsarchive.byu.edu/facpub/4875 


\title{
Same-sex parenting and children's outcomes: A closer examination of the American psychological association's brief on lesbian and gay parenting
}

\author{
Loren Marks* \\ Louisiana State University, 341 School of Human Ecology, Baton Rouge, LA 70803, United States
}

\section{A R T I C L E I N F O}

\section{Article history:}

Received 3 October 2011

Revised 8 March 2012

Accepted 12 March 2012

\section{Keywords:}

Same-sex parenting

Lesbian

Gay

\begin{abstract}
A B S T R A C T
In 2005, the American Psychological Association (APA) issued an official brief on lesbian and gay parenting. This brief included the assertion: "Not a single study has found children of lesbian or gay parents to be disadvantaged in any significant respect relative to children of heterosexual parents" (p. 15). The present article closely examines this assertion and the 59 published studies cited by the APA to support it. Seven central questions address: (1) homogeneous sampling, (2) absence of comparison groups, (3) comparison group characteristics, (4) contradictory data, (5) the limited scope of children's outcomes studied, (6) paucity of long-term outcome data, and (7) lack of APA-urged statistical power. The conclusion is that strong assertions, including those made by the APA, were not empirically warranted. Recommendations for future research are offered.
\end{abstract}

(c) 2012 Elsevier Inc. All rights reserved.

\section{Introduction}

Over the past few decades, differences have been observed between outcomes of children in marriage-based intact families and children in cohabiting, divorced, step, and single-parent families in large, representative samples. ${ }^{1}$ Based on four nationally representative longitudinal studies with more than 20,000 total participants, McLanahan and Sandefur conclude:

Children who grow up in a household with only one biological parent are worse off, on average, than children who grow up in a household with both of their biological parents. . regardless of whether the resident parent remarries. ${ }^{2}$

Differences have recurred in connection with myriad issues of societal-level concern including: (a) health, ${ }^{3}$ mortality, ${ }^{4}$ and suicide risks, ${ }^{5}$ (b) drug and alcohol abuse, ${ }^{6}$ (c) criminality and incarceration, ${ }^{7}$ (d) intergenerational poverty, ${ }^{8}$ (e) education and/ or labor force contribution, ${ }^{9}$ (f) early sexual activity and early childbearing, ${ }^{10}$ and (g) divorce rates as adults. ${ }^{11}$ These outcomes represent important impact variables that influence the well-being of children and families, as well as the national economy.

\footnotetext{
* Fax: +1 2255782697.

E-mail address: lorenm@lsu.edu

1 See Table 2; McLanahan and Sandefur (1994) and Wilcox et al. (2005).

${ }^{2}$ McLanahan and Sandefur (1994), p. 1 (emphasis in original).

${ }^{3}$ Waite (1995).

${ }^{4}$ Gaudino et al. (1999) and Siegel et al. (1996).

${ }^{5}$ Wilcox et al. (2005, p. 28) and Cutler et al. (2000).

${ }^{6}$ Bachman et al. (1997), Flewelling and Bauman (1990), Horwitz et al. (1996), Johnson etal. (1996), Simon (2002), Waite and Gallagher (2000), Weitoft et al. (2003), and Wilcox et al. (2005).

7 Blackmon et al. (2005), Harper and McLanahan (2004), Kamark and Galston (1990, pp. 14-15), Manning and Lamb (2003), and Margolin (1992, p. 546).

${ }^{8}$ Akerlof (1998), Blackmon et al. (2005), Brown (2004), Oliver and Shapiro (1997), Rank and Hirschl (1999).

${ }_{9}^{9}$ Amato (2005), Battle (1998), Cherlin etal. (1998), Heiss (1996), Lansford (2009), Manning and Lamb (2003), McLanahan and Sandefur (1994), Phillips and Asbury (1993), and Teachman et al. (1998).

${ }_{10}$ Amato (2005), Amato and Booth (2000), Ellis et al. (2003), and McLanahan and Sandefur (1994).

11 Cherlin et al. (1995) and Wolfinger (2005).
} 
By way of comparison, social science research with small convenience samples has repeatedly reported no significant differences between children from gay/lesbian households and heterosexual households. These recurring findings of no significant differences have led some researchers and professional organizations to formalize related claims. Perhaps none of these claims has been more influential than the following from the 2005 American Psychological Association (APA) Brief on "Lesbian and Gay Parenting". ${ }^{12,13}$

Not a single study has found children of lesbian or gay parents to be disadvantaged in any significant respect relative to children of heterosexual parents.

Are we witnessing the emergence of a new family form that provides a context for children that is equivalent to the traditional marriage-based family? Many proponents of same-sex marriage contend that the answer is yes. Others are skeptical and wonder-given that other departures from the traditional marriage-based family form have been correlated with more negative long-term child outcomes-do children in same-sex families demonstrably avoid being "disadvantaged in any significant respect relative to children of heterosexual parents" as the APA Brief asserts? This is a question with important implications, particularly since the 2005 APA Brief on "Lesbian and Gay Parenting" has been repeatedly invoked in the current same-sex marriage debate.

\section{Statement of purpose}

The overarching question of this paper is: Are the conclusions presented in the 2005 APA Brief on "Lesbian and Gay Parenting" valid and precise, based on the cited scientific evidence ${ }^{14}$ In the present paper, seven questions relating to the cited scientific evidence are posed, examined, and addressed. ${ }^{15}$

Two portions of the APA Brief are of particular concern to us in connection with these questions: (a) the "Summary of Research Findings" (pp. 5-22), and (b) the first and largest section of the annotated bibliography, entitled "Empirical Studies Specifically Related to Lesbian and Gay Parents and Their Children" (pp. 23-45). In the latter section (pp. 23-45), the APA references 67 manuscripts. Eight of these studies are "unpublished dissertations". ${ }^{16}$ The 59 published studies are listed in Table 1 of this paper, providing clear parameters from which to formulate responses to the seven outlined questions, next.

\subsection{Question 1: how representative and culturally, ethnically, and economically diverse were the gay/lesbian households in the} published literature behind the APA brief?

In response to question 1, more than three-fourths (77\%) of the studies cited by the APA brief are based on small, nonrepresentative, convenience samples of fewer than 100 participants. Many of the non-representative samples contain far fewer than 100 participants, including one study with five participants (Wright, 1998; see Table 1). As Strasser (2008) notes:

Members of the LGBT community. . .vary greatly in their attitudes and practices. For this reason, it would be misleading to cite a study of gay men in urban southern California as if they would represent gay men nationally (p. 37).

By extension, it seems that influential claims by national organizations should be based, at least partly, on research that is nationally representative.

Lack of representativeness often entails lack of diversity as well. ${ }^{17}$ A closer examination of the APA-cited literature from the "Empirical Studies" (pp. 23-45) section of the APA Brief reveals a tendency towards not only non-representative but racially homogeneous samples. For example:

\footnotetext{
12 The APA Briefs stated objective was primarily to influence family law. The preface states that "the focus of the publication... [is] to serve the needs of psychologists, lawyers, and parties in family law cases.... Although comprehensive, the research summary is focused on those issues that often arise in family law cases involving lesbian mothers or gay fathers" (APA Brief, 2005, p. 3). Redding (2008) reports that "leading professional organizations including the American Psychological Association" have issued statements and that "advocates have used these research conclusions to bolster support for lesbigay parenting and marriage rights, and the research is now frequently cited in public policy debates and judicial opinions" (p. 136).

13 Patterson, p. 15 (from APA Brief, 2005).

${ }^{14}$ Kuhn (1970/1996) has stated that there is an "insufficiency of methodological directives, by themselves, to dictate a unique substantive conclusion to many sorts of scientific questions" (p. 3). To draw substantive conclusions, a socially and historically influenced paradigm is needed. Research is then "directed to the articulation of those phenomena and theories that the paradigm already supplies" (p. 24). Indeed, paradigmatic biases, and other influences, can make us vulnerable to "discrepancies between warranted and stated conclusions in the social sciences" (Glenn, 1989, p. 119; see also Glenn, 1997).

${ }^{15}$ Kuhn (1970/1996) has noted that "when scientists disagree about whether the fundamental problems of their field have been solved, the search for rules gains a function that it does not ordinarily possess" (p. 48).

${ }_{16}$ These unpublished dissertations includełand (1991), McPherson (1993), Osterweil (1991), Paul (1986), Puryear (1983), Rees (1979), Sbordone (1993), and Steckel (1985). An adapted portion of one of these dissertations (Steckel, 1985) was eventually published (Steckel, 1987) and is included in the present examination; the other unpublished work is not included in Table 1 of this paper.

17 Of the 59 published "Empirical Studies Specifically Related to Lesbian and Gay Parents and Their Children", no studies mention African-American, Hispanic, or Asian-American families in either their titles or subtitles. The reference list in the APA Brief's "Summary of Research Findings" (pp. 15-22) is also void of any studies focusing on African-American, Hispanic, or Asian-American families. None of the "Empirical Studies Specifically Related to Lesbian and Gay Parents and Their Children" (pp. 23-45) holds, as its focus, any of these minorities. (Note: Three years after the 2005 APA Brief, Moore (2008) published a small but pioneering study on African-American lesbians.)
} 
Table 1

Publications Cited in APA brief on lesbian and gay parenting (pp. 23-45).

\begin{tabular}{|c|c|c|c|c|c|c|c|}
\hline Author and year & GayLes $N$ & Hetero $N$ & Stat used & $\begin{array}{l}\text { Cohen } \\
N\end{array}$ & $\begin{array}{l}\text { Stat } \\
\text { power }\end{array}$ & Outcome studied & $\begin{array}{l}\text { Hetero compar } \\
\text { group }\end{array}$ \\
\hline Bailey et al. (1995) & 55par; 82chl & 0 & T-test/Chi & 393 & N/A & Sexual orientation & None \\
\hline $\begin{array}{l}\text { Barrett and Tasker } \\
\quad(2001)\end{array}$ & 101 & 0 & T-test/Chi & 393 & $\mathrm{~N} / \mathrm{A}$ & Child responses to a gay parent & None \\
\hline $\begin{array}{l}\text { Bigner and Jacobsen } \\
\text { (1989a) }\end{array}$ & 33 & 33 & T-test & 393 & No & $\begin{array}{l}\text { Parents reports of values of } \\
\text { children }\end{array}$ & Fathers \\
\hline $\begin{array}{l}\text { Bigner and Jacobsen } \\
\text { (1989b) }\end{array}$ & 33 & 33 & T-test & 393 & No & Parent reports of parent behavior & Fathers \\
\hline Bos et al. (2003) & 100 & 100 & MANOVA & 393 & No & Parental motives and desires & Families \\
\hline Bos et al. (2004) & 100 & 100 & MANOVA & 393 & No & $\begin{array}{l}\text { Parent reports of couple } \\
\text { relations }\end{array}$ & Families \\
\hline Bozett (1980) & 18 & 0 & Qualitative & $\mathrm{N} / \mathrm{A}$ & $\mathrm{N} / \mathrm{A}$ & $\begin{array}{l}\text { Father disclosure of } \\
\text { homosexuality }\end{array}$ & None \\
\hline Brewaeys et al. (1997) & 30 & 68 & ANOVA & 393 & No & Emotional/gender development & $\begin{array}{l}\text { DI/Non-DI } \\
\text { Couples }\end{array}$ \\
\hline Chan et al. (1998a) & 30 & 16 & Various & 393 & No & $\begin{array}{l}\text { Division of labor/child } \\
\text { adjustment }\end{array}$ & DI Couples \\
\hline Chan et al. (1998b) & 55 & 25 & Various & 393 & Reported & Psychosocial adjustment & DI Couples \\
\hline $\begin{array}{l}\text { Ciano-Boyce and } \\
\quad \text { Shelley-Sireci (2002) }\end{array}$ & 67 & 44 & ANOVA & 393 & No & Division of child care & Adoptive Parents \\
\hline Crawford et al. (1999) & 0 & 0 & MANOVA & 393 & $\mathrm{~N} / \mathrm{A}$ & 388 Psychologists' attitudes & $\mathrm{N} / \mathrm{A}$ \\
\hline Flaks et al. (1995) & 15 & 15 & MANOVA & 393 & No & Cognitive/behavioral/parenting & Married Couples \\
\hline Fulcher et al. (2002) & 55 & 25 & T-test/Chi & 393 & Reported & DI/adult-child relationships & Parents \\
\hline Gartrell et al. (1996) & 154 & 0 & Descript. & $\mathrm{N} / \mathrm{A}$ & N/A & Prospective Parent Reports & None \\
\hline Gartrell et al. (1999) & 156 & 0 & Descript. & $\mathrm{N} / \mathrm{A}$ & $\mathrm{N} / \mathrm{A}$ & Reports on parenting issues & None \\
\hline Gartrell et al. (2000) & 150 & 0 & Descript. & $\mathrm{N} / \mathrm{A}$ & $\mathrm{N} / \mathrm{A}$ & Reports on parenting issues & None \\
\hline Gartrell et al. (2005) & 74 & 0 & Descript. & $\mathrm{N} / \mathrm{A}$ & N/A & Health, school/education & None \\
\hline Gershon et al. (1999) & 76 & 0 & Reg. & 390 & $\mathrm{~N} / \mathrm{A}$ & Adolescent coping & None \\
\hline Golombok et al. (1983) & 27 & 27 & T-test/Chi & 393 & No & Psychosexual development & $\begin{array}{l}\text { Single mother } \\
\text { families }\end{array}$ \\
\hline Golombok et al. (2003) & 39 & 134 & Various & 393 & No & Socioemotional dev./relations & $\begin{array}{l}\text { Couples \& } \\
\text { singles }\end{array}$ \\
\hline $\begin{array}{l}\text { Golombok and Rust } \\
\text { (1993) }\end{array}$ & $\mathrm{N} / \mathrm{A}$ & $\mathrm{N} / \mathrm{A}$ & $\mathrm{N} / \mathrm{A}$ & $\mathrm{N} / \mathrm{A}$ & $\mathrm{N} / \mathrm{A}$ & $\begin{array}{l}\text { Reliability testing of a pre-school } \\
\text { gender inventory }\end{array}$ & \\
\hline $\begin{array}{l}\text { Golombok and Tasker } \\
\text { (1996) }\end{array}$ & 25 & 21 & Pearson & 783 & Reported & Sexual orientation & $\begin{array}{l}\text { Children of } \\
\text { single mothers }\end{array}$ \\
\hline Golombok et al. (1997) & 30 & 83 & MANOVA & 393 & No. & Parent-child interactions & $\begin{array}{l}\text { Couples \& } \\
\text { singles }\end{array}$ \\
\hline Green (1978) & 37 & 0 & Descript. & $\mathrm{N} / \mathrm{A}$ & $\mathrm{N} / \mathrm{A}$ & Sexual identity & None \\
\hline Green et al. (1986) & 50par; 56chl & 40par; 48chl & Various & 390 & No & Sexual identity/social relations & Single mothers \\
\hline $\begin{array}{l}\text { Harris and Turner } \\
\text { (1986) }\end{array}$ & 23 & 16 & ANOVA/Chi & 393 & No & Sex roles/relationship with child & $\begin{array}{l}\text { Single moth. \& } \\
\text { fath. }\end{array}$ \\
\hline Hoeffer (1981) & 20 & 20 & ANOVA & 393 & No & Sex-role behavior & Single mothers \\
\hline Huggins (1989) & 18 & 18 & T-test & 393 & No & $\begin{array}{l}\text { Self-esteem of adolescent } \\
\text { children }\end{array}$ & $\begin{array}{l}\text { Divorced } \\
\text { mothers }\end{array}$ \\
\hline $\begin{array}{l}\text { Johnson and O'Connor } \\
\text { (2002) }\end{array}$ & 415 & 0 & Various & $\mathrm{N} / \mathrm{A}$ & No & $\begin{array}{l}\text { Parenting beliefs/division of } \\
\text { labor/etc. }\end{array}$ & None \\
\hline King and Black (1999) & $\mathrm{N} / \mathrm{A}$ & $\mathrm{N} / \mathrm{A}$ & $\mathrm{F}$ & 393 & $\mathrm{~N} / \mathrm{A}$ & $\begin{array}{l}338 \text { College students' } \\
\text { perceptions }\end{array}$ & $\mathrm{N} / \mathrm{A}$ \\
\hline Kirkpatrick et al. (1981) & 20 & 20 & Descript. & $\mathrm{N} / \mathrm{A}$ & No & Gender development & Single mothers \\
\hline Koepke et al. (1992) & 47 couples & 0 & MANOVA & $\mathrm{N} / \mathrm{A}$ & $\mathrm{N} / \mathrm{A}$ & Relationship quality & None \\
\hline Kweskin and Cook, 1982 & 22 & 22 & Chi-Sqr & 785 & No & Sex-role behavior & Single mothers \\
\hline Lewis, 1980 & 21 & 0 & Qualitative & $\mathrm{N} / \mathrm{A}$ & N/A & Child response to $\mathrm{m}$. disclosure & None \\
\hline $\begin{array}{l}\text { Lott-Whitehead and } \\
\text { Tully, } 1993\end{array}$ & 45 & 0 & Descriptive & $\mathrm{N} / \mathrm{A}$ & $\mathrm{N} / \mathrm{A}$ & $\begin{array}{l}\text { Adult reports of impacts on } \\
\text { children }\end{array}$ & None \\
\hline Lyons, 1983 & 43 & 37 & Descriptive & $\mathrm{N} / \mathrm{A}$ & No & Adult self-reports & $\begin{array}{l}\text { Divorced } \\
\text { mothers }\end{array}$ \\
\hline McLeod et al., 1999 & 0 & 0 & Mult. regr. & $\mathrm{N} / \mathrm{A}$ & No & 151 College student reports & N/A \\
\hline Miller, 1979 & 54 & 0 & Qualitative & $\mathrm{N} / \mathrm{A}$ & $\mathrm{N} / \mathrm{A}$ & Father behavior \& f-child bond & None \\
\hline Miller et al., 1981 & 34 & 47 & Chi-Sqr & 785 & No & Mother role/home environment & Mothers \\
\hline Morris et al., 2002 & 2431 & 0 & MANCOVA & $\mathrm{N} / \mathrm{A}$ & $\mathrm{N} / \mathrm{A}$ & Adult reports on "coming out" & None \\
\hline $\begin{array}{l}\text { Mucklow and Phelan, } \\
1979\end{array}$ & 34 & 47 & Chi-Sqr & 785 & No & Behavior and self-concept & Married mothers \\
\hline O’Connell, 1993 & 11 & 0 & Qualitative & $\mathrm{N} / \mathrm{A}$ & $\mathrm{N} / \mathrm{A}$ & Social and sexual identity & None \\
\hline Pagelow, 1980 & 20 & 23 & Qual/Descr. & $\mathrm{N} / \mathrm{A}$ & N/A & Problems and coping & Single mothers \\
\hline Patterson (1994) & 66 & 0 & T-test & 393 & No & Social/behavioral/sexual identity & Available norms \\
\hline Patterson (1995) & 52 & 0 & T-test/Chi/F & 393 & No & $\begin{array}{l}\text { Division of labor/child } \\
\text { adjustment }\end{array}$ & None \\
\hline
\end{tabular}


Table 1 (continued)

\begin{tabular}{|c|c|c|c|c|c|c|c|}
\hline Author and year & GayLes $N$ & Hetero $N$ & Stat used & $\begin{array}{l}\text { Cohen } \\
N\end{array}$ & $\begin{array}{l}\text { Stat } \\
\text { power }\end{array}$ & Outcome studied & $\begin{array}{l}\text { Hetero compar } \\
\text { group }\end{array}$ \\
\hline Patterson (2001) & 66 & 0 & Various & 393 & No & $\begin{array}{l}\text { Maternal mental health/child } \\
\text { adjustment }\end{array}$ & None \\
\hline Patterson et al., 1998 & 66 & 0 & Various & 393 & No & Contact w/grandparents \& adults & None \\
\hline Rand et al. (1982) & 25 & 0 & Correlations & 783 & No & Mothers' psychological health & None \\
\hline Sarantakos, 1996 & 58 & 116 & F-test & 393 & $\mathrm{~N} / \mathrm{A}$ & $\begin{array}{l}\text { Children's educational/social } \\
\text { outcomes }\end{array}$ & $\begin{array}{l}\text { Married/non- } \\
\text { married }\end{array}$ \\
\hline $\begin{array}{l}\text { Siegenthaler and Bigner, } \\
2000\end{array}$ & 25 & 26 & T-test & 393 & No & Mothers' value of children & Mothers \\
\hline Steckel (1987) & (Review) & $\mathrm{N} / \mathrm{A}$ & $\mathrm{N} / \mathrm{A}$ & $\mathrm{N} / \mathrm{A}$ & No & $\begin{array}{l}\text { Psychosocial development of } \\
\text { children }\end{array}$ & None \\
\hline Sullivan, 1996 & 34 couples & 0 & Qualitative & $\mathrm{N} / \mathrm{A}$ & $\mathrm{N} / \mathrm{A}$ & Division of labor & None \\
\hline $\begin{array}{l}\text { Tasker and Golombok, } \\
1995\end{array}$ & 25 & 21 & Pearson/T & 783 & No & Psychosocial/sexual orientation & Single mothers \\
\hline $\begin{array}{l}\text { Tasker and Golombok } \\
\text { (1997) }\end{array}$ & 27 & 27 & Various & 393 & Reported & $\begin{array}{l}\text { Psychological outcomes/family } \\
\text { rel. }\end{array}$ & Single mothers \\
\hline $\begin{array}{l}\text { Tasker and Golombok } \\
\text { (1998) }\end{array}$ & 15 & 84 & $\begin{array}{l}\text { ANCOVA/ } \\
\text { Chi }\end{array}$ & 785 & $\mathrm{~N} / \mathrm{A}$ & Work and family life & DI \& NC couples \\
\hline $\begin{array}{l}\text { Vanfraussen et al. } \\
\text { (2003) }\end{array}$ & 24 & 24 & ANOVA & 393 & No & $\begin{array}{l}\text { Donor insemination/family } \\
\text { funct. }\end{array}$ & Families \\
\hline Wainwright et al. (2004) & 44 & 44 & Various & 393 & No & Psychosocial/school/romantic & Couples \\
\hline Wright (1998) & 5 & 0 & Qualitative & $\mathrm{N} / \mathrm{A}$ & $\mathrm{N} / \mathrm{A}$ & $\begin{array}{l}\text { Family issues/processes/ } \\
\text { meaning }\end{array}$ & None \\
\hline
\end{tabular}

$\mathrm{N} / \mathrm{A}=$ Not applicable (e.g., In connection with statistical power, qualitative studies and studies without heterosexual comparison groups are coded as N/A).

1. "All of [the fathers in the sample] were Caucasian" (Bozett, 1980, p. 173).

2. "Sixty parents, all of whom were White" comprised the sample (Flaks et al., 1995, p. 107).

3. "[All 40] mothers... .were white" (Hoeffer, 1981, p. 537).

4. "All the children, mothers, and fathers in the sample were Caucasian" (Huggins, 1989, p. 126).

5. "The 25 women were all white" (Rand et al., 1982, p. 29).

6. "All of the women... [were] Caucasian" (Siegenthaler and Bigner, 2000, p. 82).

7. "All of the birth mothers and co-mothers were white" (Tasker and Golombok, 1998, p. 52).

8. “All [48] parents were Caucasian" (Vanfraussen et al., 2003, p. 81).

Many of the other studies do not explicitly acknowledge all-White samples, but also do not mention or identify a single minority participant-while a dozen others report "almost" all-white samples. ${ }^{18}$ Same-sex family researchers Lott-Whitehead and Tully (1993) cautiously added in the discussion of their APA Brief-cited study:

Results from this study must be interpreted cautiously due to several factors. First, the study sample was small $(N=45)$ and biased toward well-educated, white women with high incomes. These factors have plagued other [same-sex parenting] studies, and remain a concern of researchers in this field (p. 275).

Similarly, in connection with this bias, Patterson (1992), who would later serve as sole author of the 2005 APA Brief's "Summary of Research Findings on Lesbian and Gay Families", reported ${ }^{19}$ :

Despite the diversity of gay and lesbian communities, both in the United States and abroad, samples of children [and parents] have been relatively homogeneous.... Samples for which demographic information was reported have been described as predominantly Caucasian, well-educated, and middle to upper class.

In spite of the privileged and homogeneous nature of the non-representative samples employed in the studies at that time, Patterson's (1992) conclusion was as follows ${ }^{20}$ :

Despite shortcomings [in the studies], however, results of existing research comparing children of gay or lesbian parents with those of heterosexual parents are extraordinarily clear, and they merit attention... There is no evidence to suggest that psychosocial development among children of gay men or lesbians is compromised in any respect relative to that among offspring of heterosexual parents.

\footnotetext{
${ }^{18}$ Examples of explicit or implicitly all-White (or nearly all-White) samples include, but are not limited to: Bigner andjacobsen (1989a,b), Bozett (1980), Flaks et al. (1995), Green (1978), Green etal. (1986), Hoeffer (1981), Huggins (1989), Koepke et al. (1992), Rand et al. (1982), Siegenthaler and Bigner (2000), Tasker and Golombok (1995, 1998), Vanfraussen et al. (2003).

19 Patterson (1992, p. 1029).

20 Patterson (1992, p. 1036) (emphasis added).
} 
Patterson's conclusion in a 2000 review was essentially the same ${ }^{21}$ :

[C]entral results of existing research on lesbian and gay couples and families with children are exceptionally clear.... [The] home environments provided by lesbian and gay parents are just as likely as those provided by heterosexual parents to enable psychosocial growth among family members.

Although eight years had passed, in this second review, Patterson (2000) reported the continuing tendency of same-sex parenting researchers to select privileged lesbian samples. Specifically, she summarized, "Much of the research [still] involved small samples that are predominantly White, well-educated [and] middle-class" (p. 1064). ${ }^{22}$ Given the privileged, homogeneous, and non-representative samples of lesbian mothers employed in "much of the research", it seems warranted to propose that Patterson was empirically premature to conclude that comparisons between "gay or lesbian parents" and "heterosexual parents" were "extraordinarily clear" 23 or "exceptionally clear". 24

There is an additional point that warrants attention here. In Patterson's statements above, there are recurring references to research on children of "gay" men/parents. In 2000, Demo and Cox reported that "children living with gay fathers" was a "rarely studied household configuration". ${ }^{25}$ In 2005, how many of the 59 published studies cited in the APA's list of "Empirical Studies Specifically Related to Lesbian and Gay Parents and Their Children" ( $p$. 23-45) specifically addressed the outcomes of children from gay fathers? A closer examination reveals that only eight studies did so. ${ }^{26}$ Of these eight studies, four did not include a heterosexual comparison group. ${ }^{27}$ In three of the four remaining studies (with heterosexual comparison groups), the outcomes studied were:

(1) "the value of children to...fathers" (Bigner and Jacobsen, 1989a, p. 163);

(2) "parenting behaviors of. . .fathers" (Bigner and Jacobsen, 1989b, p. 173);

(3) "problems" and "relationship with child" (Harris and Turner, 1986, pp. 107-8).

The two Bigner and Jacobsen (1989a,b) studies focused on fathers' reports of fathers' values and behaviors, not on children's outcomes-illustrating a recurring tendency in the same-sex parenting literature to focus on the parent rather than the child. Harris and Turner (1986) addressed parent-child relationships, but their study's male heterosexual comparison group was composed of two single fathers. Although several studies have examined aspects of gay fathers' lives, none of the studies comparing gay fathers and heterosexual comparison groups referenced in the APA Brief (pp. 23-45) appear to have specifically focused on children's developmental outcomes, with the exception of Sarantakos (1996), a study to which we will later return.

In summary response to question 1 ("How representative and culturally, ethnically, and economically diverse were the gay/lesbian households in the published literature behind the APA Brief?"), we see that in addition to relying primarily on small, non-representative, convenience samples, many studies do not include any minority individuals or families. Further, comparison studies on children of gay fathers are almost non-existent in the 2005 Brief. By their own reports, social researchers examining same-sex parenting have repeatedly selected small, non-representative, homogeneous samples of privileged lesbian mothers to represent all same-sex parents. This pattern across three decades of research raises significant questions regarding lack of representativeness and diversity in the same-sex parenting studies.

\subsection{Question 2: how many studies of gay/lesbian parents had no heterosexual comparison group?}

Of the 59 publications cited by the APA in the annotated bibliography section entitled "Empirical Studies Specifically Related to Lesbian and Gay Parents and Their Children" (pp. 23-45), 33 included a heterosexual comparison group. In direct response to question 2, 26 of the studies (44.1\%) on same-sex parenting did not include a heterosexual comparison group. In well-conducted science, it is important to have a clearly defined comparison group before drawing conclusions regarding differences or the lack thereof. We see that nearly half of the "Empirical Studies Specifically Related to Lesbian and Gay Parents and Their Children" referenced in the APA Brief allowed no basis for comparison between these two groups (see Table 1). To proceed with precision, this fact does not negate the APA claim. It does, however, dilute it considerably as we are left with not 59, but 33, relevant studies with heterosexual comparison groups.

\subsection{Question 3: when heterosexual comparison groups were used, what were the more specific characteristics of those groups?}

We now turn to a question regarding the nature of comparison samples. Of the 33 published "Empirical Studies Specifically Related to Lesbian and Gay Parents and Their Children" (APA Brief, pp. 23-45) that did directly include a heterosexual

\footnotetext{
21 Patterson (2000, , p. 1064) (emphasis added).

22 Patterson (2000, p. 1064).

23 Patterson (1992, p. 1036).

24 Patterson (2000, p. 1064).

25 Demo and Cox (2000, p. 890).

26 Bailey et al. (1995), Barrett and Tasker (2001), Bigner and Jacobsen (1989a,b), Bozett (1980), Harris and Turner (1986), Miller (1979), Sarantakos (1996).

27 Bailey et al. (1995), Barrett and Tasker (2001), Bozett (1980), Miller (1979).
} 
Table 2

Brief overview of 15 intact/divorce/step/single family studies.

\begin{tabular}{|c|c|c|c|c|}
\hline $\begin{array}{l}(N) \\
\text { Probability } \\
\text { Comp Grp } \\
\text { Long } \\
\text { Key }\end{array}$ & $\begin{array}{l}\text { Number of reported part } \\
\text { Is the study based on a } \\
\text { Is a probability sample } u \\
\text { Does the study employ } \\
!=\text { Yes; } X=\text { No }\end{array}$ & $\begin{array}{l}\text { group? } \\
\text { ss time? }\end{array}$ & & \\
\hline Key & $(N)$ & Probability & Comp Grp & Long \\
\hline Amato (1991) & 9643 & $!$ & $!$ & $!$ \\
\hline Aquilino (1994) & 4516 & $!$ & $!$ & $!$ \\
\hline Brown $(2004)^{a}$ & 35,938 & $!$ & $!$ & $\mathrm{X}$ \\
\hline Chase-Lansdale et al. (1995) ${ }^{\mathrm{b}}$ & 17,414 & $!$ & $!$ & $!$ \\
\hline Cherlin et al. $(1998)^{c}$ & 11,759 & $!$ & $!$ & ! \\
\hline Ellis et al. (2003) & 762 & $!$ & $!$ & $!$ \\
\hline Harper and McLanahan (2004) ${ }^{\mathrm{d}}$ & 2846 & $!$ & $!$ & $!$ \\
\hline Hetherington and Kelly (2002) & 1400 & $!$ & $!$ & $!$ \\
\hline Jekielek (1998) & 1640 & $!$ & $!$ & $!$ \\
\hline Lichter et al. $(2003)^{\mathrm{f}}$ & 7665 & $!$ & $!$ & $\mathrm{X}$ \\
\hline Manning and Lamb (2003) & 13,231 & $!$ & $!$ & $\mathrm{X}$ \\
\hline \multicolumn{5}{|c|}{ McLanahan and Sandefur (1994) (based on four data sets) } \\
\hline PSID & 2900 & $!$ & $!$ & $!$ \\
\hline NLSY ${ }^{h}$ & 5246 & $!$ & $!$ & $!$ \\
\hline HSBS $^{\mathrm{i}}$ & 10,400 & ! & $!$ & $!$ \\
\hline $\mathrm{NSFH}^{\mathrm{j}}$ & $13,017^{\mathrm{k}}$ & ! & ! & $!$ \\
\hline Mitchell et al. (2009) ${ }^{1}$ & 4663 & $!$ & $!$ & $!$ \\
\hline Nock $(1998)^{\mathrm{m}}$ & 3604 & $!$ & $!$ & $!$ \\
\hline Page and Stevens $(2005)^{\mathrm{n}}$ & 2023 & $!$ & $!$ & $!$ \\
\hline Total & 148,667 & & & \\
\hline
\end{tabular}

a National Survey of America's Families (NSAF)

b United Kingdom study and sample.

c United Kingdom study and sample.

d National Longitudinal Survey of Young Men and Women (NLSY).

e Virginia Longitudinal Study (VLS).

f National Survey of Family Growth (NSFG).

g Panel Study of Income Dynamics (PSID).

h National Longitudinal Survey of Young Men and Women (NLSY).

i The High School and Beyond Study (HSBS).

j National Survey of Families and Households (NSFH).

$\mathrm{k}$ This is the total original sample. The sub-sample is unlisted but is likely smaller.

${ }^{1}$ National Longitudinal Study of Adolescent Health (Add Health).

m National Longitudinal Survey of Young Men and Women (NLSY).

n Panel Study of Income Dynamics (PSID).

comparison group, what were the more specific characteristics of the groups that were compared? The earlier examination and response related to question 1 documented that, by Patterson's reports, "Despite the diversity of gay and lesbian communities. . .in the United States", ${ }^{28}$ the repeatedly selected representatives of same-sex parents have been "small samples [of lesbians] that are predominantly White, well-educated [and] middle-class" (p. 1064). ${ }^{29}$

In spite of homogeneous sampling, there is considerable diversity among gay and lesbian parents. Considerable diversity exists among heterosexual parents as well. Indeed, the opening paragraph of the present article noted recurring differences in several outcomes of societal concern for children in marriage-based intact families compared with children in cohabiting, divorced, step, and single-parent families. ${ }^{30}$ Many of the cited findings are based on probability samples of thousands (see Table 2).

Because children in marriage-based intact families have historically fared better than children in cohabiting, divorced, step, or single-parent families on the above outcomes, the question of what "groups" researchers selected to represent heterosexual parents in the same-sex parenting studies becomes critical. A closer examination of the 33 published same-sex parenting studies (APA Brief, pp. 23-45) with comparison groups, listed chronologically, reveals that:

1. Pagelow (1980) used "single mothers" as a comparison group (p. 198).

2. Hoeffer (1981) used "heterosexual single mothers" (p. 537).

3. Kirkpatrick et al. (1981) used "single, heterosexual mothers" (p. 545).

4. Kweskin and Cook (1982) used women from Parents without Partners (p. 969).

\footnotetext{
28 Patterson (1992, p. 1029).

29 Patterson (2000, p. 1064).

30 See Footnotes 2-10 for documentation.
} 
5. Lyons (1983) used "heterosexual single mothers" (p. 232).

6. Golombok et al. (1983) used "single-parent households" (p. 551).

7. Green et al. (1986) used "solo parent heterosexual mothers" (p. 175).

8. Harris and Turner (1986) used 2 "male single parents" and 14 "female single parents" (p. 105).

9. Huggins (1989) used "divorced heterosexual mothers"31 (p. 123).

10. Tasker and Golombok (1995) used "heterosexual single mothers" (p. 203).

11. Tasker and Golombok (1997) used "single heterosexual mothers" (p. 38).

We see that in selecting heterosexual comparison groups for their studies, many same-sex parenting researchers have not used marriage-based, intact families as heterosexual representatives, but have instead used single mothers (see Table 1). Further, Bigner and Jacobsen used 90.9 percent single-father samples in two other studies (1989a, 1989b). ${ }^{32}$ In total, in at least 13 of the 33 comparison studies listed in the APA Brief's list of "Empirical Studies" (pp. 23-45) that include heterosexual comparison groups, the researchers explicitly sampled "single parents" as representatives for heterosexual parents. The repeated (and perhaps even modal) selection of single-parent families as a comparison heterosexual-parent group is noteworthy, given that a Child Trends (2002) review has stated that "children in single-parent families are more likely to have problems than are children who live in intact families headed by two biological parents". ${ }^{33}$

Given that at least 13 of the 33 comparison studies listed in the APA Brief's list of "Empirical Studies" (pp. 23-45) used single-parent families as heterosexual comparison groups, what group(s) did the remaining 20 studies use as heterosexual representatives? In closely examining the 20 remaining published comparison group studies, it is difficult to formulate precise reports of the comparison group characteristics, because in many of these studies, the heterosexual comparison groups are referred to as "mothers" or "couples" without appropriate specificity (see Table 1). Were these mothers continuously married-or were they single, divorced, remarried, or cohabiting? When couples were used, were they continuously married-or remarried or cohabiting? These failures to explicitly and precisely report sample characteristics (e.g., married or cohabiting) are significant in light of Brown's (2004) finding based on her analysis of a data set of 35,938 US children and their parents, that "regardless of economic and parental resources, the outcomes of adolescents (12-17 years old) in cohabiting families... are worse...than those. . in two-biological-parent married families". ${ }^{34}$ Because of the disparities noted by Brown and others, scientific precision requires that we know whether researchers used: (a) single mothers, (b) cohabiting mothers and couples, (c) remarried mothers, or (d) continuously married mothers and couples as heterosexual comparison groups.

Due to the ambiguity of the characteristics of the heterosexual samples in many same-sex parenting studies, let us frame a question that permits a more precise response, namely: How many of the studies in the APA Briefs "Empirical Studies" section (pp. 23-45) explicitly compare the outcomes of children from intact, marriage-based families with those from same-sex families? In an American Psychologist article published the year after the APA Brief, Herek (2006) referred to a large, national study by McLanahan and Sandefur (1994) "comparing the children of intact heterosexual families with children being raised by a single parent". Herek then emphasized that "this [large scale] research literature does not include studies comparing children raised by two-parent same-sex couples with children raised by two-parent heterosexual couples" ${ }^{35}$ Isolated exceptions exist with relatively small samples (as discussed shortly in response to question 4 and as listed in Table 1), but they are rare.

Given what we have seen regarding heterosexual comparison group selection, let us revisit three related claims. First, in 1992, Patterson posited that ${ }^{36}$ :

[N]ot a single study has found children of gay and lesbian parents to be disadvantaged in any respect relative to children of heterosexual parents.

Patterson's (2000) claim was similar ${ }^{37}$ :

[C]entral results of existing research on lesbian and gay couples and families with children are exceptionally clear.... [The] home environments provided by lesbian and gay parents are just as likely as those provided by heterosexual parents to enable psychosocial growth among family members.

Lastly, and most significantly, we turn to the APA Brief's "Summary of Research Findings on Lesbian and Gay Parenting", also single-authored by Patterson (see p. 5) ${ }^{38}$ :

Not a single study has found children of lesbian or gay parents to be disadvantaged in any significant respect relative to children of heterosexual parents.

\footnotetext{
31 "Four of the 16 [divorced] heterosexual mothers were either remarried or currently living with a heterosexual lover" (p. 127).

32 "Of the 66 respondents, six were married, 48 were divorced, eight were separated, and four had never been married" (Bigner and Jacobsen (1989a, p. 166).

This means the sample was $90.9 \%$ single.

33 Moore et al. (2002); for an extensive review, see Wilcox et al. (2011).

34 Brown (2004, p. 364) (emphasis added).

35 Herek (2006, p. 612).

36 Patterson (1992, p. 1036) (emphasis added).

37 Patterson (2000, p. 1064) (emphasis added).

38 Patterson, p. 15 (from APA Brief, 2005), (emphasis added).
} 
In all three of these claims (including that latter from the 2005 APA Brief), Patterson uses the broad and plural term "heterosexual parents", a term that includes marriage-based, intact families. This broad claim is not nuanced by the information that, with rare exceptions, the research does not include studies comparing children raised by two-parent, same-sex couples with children raised by marriage-based, heterosexual couples. Further, no mention is made that in at least 13 of the 33 extant comparison studies referenced in the Brief (pp. 23-45), the groups selected to represent "heterosexual parents" were composed largely, if not solely, of single parents. We now move to another related examination of the APA Brief.

2.4. Question 4: does a scientifically-viable study exist to contradict the conclusion that "not a single study has found children of lesbian or gay parents to be disadvantaged"?

There is at least one notable exception ${ }^{39}$ to the APA's claim that "Not a single study has found children of lesbian or gay parents to be disadvantaged in any significant respect relative to children of heterosexual parents". ${ }^{40}$ In the "Summary of Findings" section, the APA Brief references a study by Sarantakos (1996), ${ }^{41}$ but does so in a footnote that critiques the study (p. 6, Footnote 1). On page 40 of the APA Brief's annotated bibliography, a reference to the Sarantakos (1996) article is offered, but there is no summary of the study's findings, only a note reading "No abstract available".

Upon closer examination, we find that the Sarantakos (1996) study is a comparative analysis of 58 children of heterosexual married parents, 58 children of heterosexual cohabiting couples, and 58 children living with homosexual couples that were all "matched according to socially significant criteria (e.g., age, number of children, education, occupation, and socio-economic status)" ${ }^{42}$ The combined sample size (174) is the seventh-largest sample size of the 59 published studies listed in the APA Brief's "Summary of Research Findings on Lesbian and Gay Parenting" (see Table 1). However, the six studies with larger sample sizes were all adult self-report studies, ${ }^{43}$ making the Sarantakos combined sample the largest study (APA Brief, pp. 23-45) that examined children's developmental outcomes.

Key findings of the Sarantakos study are summarized below. To contextualize these data, the numbers are based on a teacher rating-scale of performance "ranging from 1 (very low performance), through 5 (moderate performance) to 9 (very high performance)". ${ }^{44}$ Based on teacher (not parent) reports, Sarantakos found several significant differences between married families and homosexual families. ${ }^{45}$

\begin{tabular}{ll}
\hline Language Achievement & Married 7.7, Cohabiting 6.8, Homosexual 5.5 \\
Mathematics Achievement & Married 7.9, Cohabiting 7.0, Homosexual 5.5 \\
Social Studies Achievement & Married 7.3, Cohabiting 7.0, Homosexual 7.6 \\
Sport Interest/Involvement & Married 8.9, Cohabiting 8.3, Homosexual 5.9 \\
Sociability/Popularity & Married 7.5, Cohabiting 6.5, Homosexual 5.0 \\
School/Learning Attitude & Married 7.5, Cohabiting 6.8, Homosexual 6.5 \\
Parent-School Relationships & Married 7.5, Cohabiting 6.0, Homosexual 5.0 \\
Support with Homework & Married 7.0, Cohabiting 6.5, Homosexual 5.5 \\
Parental Aspirations & Married 8.1, Cohabiting 7.4, Homosexual 6.5
\end{tabular}

a Sarantakos, 1996, pp. 24-27.

Sarantakos concluded, "Overall, the study has shown that children of married couples are more likely to do well at school in academic and social terms, than children of cohabiting and homosexual couples". ${ }^{46}$

The APA's decision to de-emphasize the Sarantakos (1996) study was based, in part, on the criticism that "nearly all indicators of the children's functioning were based on subjective reports by teachers". ${ }^{47}$ The Sarantakos study was based, in part, on teacher reports. However, teacher reports included "tests" and "normal school assessment" (p. 24). Subsequently, it may be

\footnotetext{
${ }^{39}$ Other arguably contradictory studies are reviewed by Schumm (2011).

40 Patterson, p. 15 (from APA Brief, 2005).

${ }^{41}$ Among the diverse types of gay/lesbian parents there are at least two major categories that warrant scholarly precision: (a) two lesbian or gay parents raising an adopted or DI (donor insemination) child from infancy with these and only these two parents; and (b) two lesbian or gay parents raising a child who is the biological offspring of one of the parents, following a separation or divorce from a heterosexual partner. The Sarantakos sample is of the latter (b) type. In terms of scholarly precision, it is important to differentiate and not draw strong implications from 'a' to 'b' or 'b' to 'a.' Indeed, the author would posit that adopted versus DI children may also warrant separate consideration. The core issue is that precision is essential and overextension of findings should be avoided. This same issue is of serious concern in connection with the tendency to overextend findings regarding lesbian mothers to apply to gay fathers (see Regnerus, this volume).

42 Sarantakos (1996, p. 23).

43 In order, these six studies include: (1) Morris et al., 2002 ( $N=2431)$, who addressed adults' reports of "coming out"; (2) Johnson and O'Connor (2002) $(N=415)$, who addressed adults' reports of parenting beliefs, division of labor, etc.; (3) Crawford et al. (1999) $(N=388)$, who addressed psychologists' selfreports of gay adoption; (4) King and Black (1999) $(N=338)$, who addressed college students' perceptions of gay parents; (5) Bos et al. (2003) $(N=200)$, who addressed parental motives and desires; and (6) Bos et al. (2004) $(N=200)$, who addressed parental reports of couple relations. These foci are not children's outcomes.

44 Sarantakos (1996, p. 24)

${ }^{45}$ Social Studies Achievement is significant at the $p=.008$ level; the eight other differences are significant at the $p=.000$ level.

46 Sarantakos (1996, p. 30)

${ }^{47}$ APA Brief (2005), Footnote 1, p. 6 (emphasis added).
} 
argued that Sarantakos' decision not to rely solely or extensively on parent reports, as is done in most same-sex parenting studies, is a strength, given parents' tendencies towards bias when reporting on their own children. ${ }^{48}$ Sarantakos ${ }^{49}$ also drew data from school aptitude tests and observations, thereby modeling a research ideal of triangulation of sources. ${ }^{50}$ In fact, the study integrated not only three data sources to triangulate; it featured at least four (i.e., teachers, tests, observations, and child reports). Further, the study controlled for "education, occupation, and socio-economic status" and then, based on teacher reports, compared marriage-based families with gay/lesbian families and found nine significant differences-with children from marriage-based families rating higher in eight areas. By objective standards, compared with the studies cited by the APA Brief, the 1996 Sarantakos study was:

(a) The largest comparison study to examine children's outcomes, ${ }^{51}$

(b) One of the most comparative (only about five other studies used three comparison groups), ${ }^{52}$ and

(c) The most comprehensively triangulated study (four data sources) conducted on same-sex parenting. ${ }^{53}$

Accordingly, this study deserves the attention of scientists interested in the question of homosexual and heterosexual parenting, rather than the footnote it received.

As we conclude the examination of question 4, let us review a portion of APA's published negation of Sarantakos' (1996) study $^{54}$ :

[Children Australia, the journal where the article was published] cannot be considered a source upon which one should rely for understanding the state of scientific knowledge in this field, particularly when the results contradict those that have been repeatedly replicated in studies published in better known scientific journals.

For other scientists, however, the salient point behind the Sarantakos findings is that the novel comparison group of marriage-based families introduced significant differences in children's outcomes (as opposed to the recurring "no difference" finding with single-mother and "couple" samples). We now turn to the fifth question.

\subsection{Question 5: what types of outcomes have been investigated?}

With respect to the APA Brief's claim that "not a single study has found children of lesbian or gay parents to [have] disadvantaged [outcomes]", what types of outcomes have been examined and investigated? Specifically, how many of the samesex parenting studies in Table 1 address the societal concerns of intergenerational poverty, collegiate education and/or labor force contribution, serious criminality, incarceration, early childbearing, drug/alcohol abuse, or suicide that are frequently the foci of national studies on children, adolescents, and young adults, as discussed at the outset of this paper?

Anderssen and colleagues cataloged the foci of same-sex parenting studies in a 2002 review and reported ${ }^{55}$ :

Emotional functioning was the most often studied outcome (12 studies), followed by sexual preference (nine studies), gender role behavior (eight studies), behavioral adjustment (seven studies), gender identity (six studies), and cognitive functioning (three studies).

Examination of the articles cited in the 2005 APA Brief on Lesbian and Gay Parenting yields a list of studied outcomes that are consistent with Anderssen's summary, including: "sexual orientation" "56; "behavioral adjustment, self-concepts, and sex-role identity"57; "sexual identity"58; "sex-role behavior"59; "self-esteem"60; " "psychosexual and psychiatric appraisal"61; "socioemotional development" ${ }^{\text {" }}$; and "maternal mental health and child adjustment". 63

\footnotetext{
48 It is well replicated that individuals tend to rate the group with which they most identify more positively than they do other groups. This positive bias includes within-family ratings Roese and Olson (2007).

49 Sarantakos is the author of several research methods textbooks (2005, 2007b) and the author/editor of a four-volume, 1672-page work in Sage Publications' Benchmarks in Social Research Series (2007a).

50 "Triangulation is a means of checking the integrity of the inferences one draws. It can involve the use of multiple data sources, ... multiple theoretical perspectives, multiple methods, or all of these" (Schwandt, 2001, p. 257). In effect, the standard of triangulation is advocacy for checks and balances.

51 Six of the 59 studies listed in the 2005 APA Brief (pp. 23-45) had larger samples, but, as discussed earlier, they all focused on adult reports of adult perceptions and outcomes.

52 For example, Brewaeys et al. (1997), Golombok et al. (2003, 1997), MacCallum and Golombok (2004), and Tasker and Golombok (1998).

53 In spite of the strong design with respect to triangulation, the Sarantakos study does not appear to be based on a true probability sample, nor is it or a large sample (although it is a subsample of a 900-plus study). The study is rigorous by comparison to other same-sex parenting studies, but is limited compared with most of the nationally representative studies on intact families listed in Table 2.

54 Patterson (2005) in APA Brief, p. 7, Footnote 1.

55 Anderssen et al. (2002, p. 343).

56 Bailey et al. (1995) and Golombok and Tasker (1996).

57 Patterson (1994).

58 Green (1978).

59 Hoeffer (1981) and Kweskin and Cook (1982).

60 Huggins (1989).

61 Golombok et al. (1983).

62 Golombok et al. (1997).

63 Patterson (2001)
} 
With these focal outcomes identified, it is noteworthy that all of the aforementioned outcomes of societal-level concern are absent from the list of "most often studied outcome(s)" as identified by Anderssen et al. ${ }^{64}$ In response to the present article's question 5 (what types of outcomes have been investigated for children of gay/lesbian families?), it may be concluded: In the same-sex parenting research that undergirded the 2005 APA Brief, it appears that gender-related outcomes were the dominant research concern. To be more precise, Table 1 lists several categories of information regarding the 59 published empirical studies; one of these categories is the "outcome studied". More than 20 studies have examined gender-related outcomes, but there was a dearth of peer-reviewed journal articles from which to form science-based conclusions in myriad areas of societal concern. ${ }^{65}$

One book-length empirical study ${ }^{66}$ entitled Same-Sex Couples (Sarantakos, 2000, Harvard Press) did examine several issues of societal concern. In connection with the questions raised in the present article, this study:

(1) includes a diverse sample of lesbian and gay parents instead of focusing on privileged lesbian mothers (question 1);

(2) uses not only one but two heterosexual comparison samples; one married parent sample and one cohabitating parent sample (questions 2 and 3);

(3) examines several outcomes of societal concern (question 5); and

(4) is unique in presenting long-term (post-18 years old) outcomes of children with lesbian and gay parents (question 6 , addressed later).

This study's conclusion regarding outcomes of gay and lesbian parents reads, in part:

If we perceive deviance in a general sense, to include excessive drinking, drug use, truancy, sexual deviance, and criminal offenses, and if we rely on the statements made by adult children (over 18 years of age)...[then] children of homosexual parents report deviance in higher proportions than children of (married or cohabiting) heterosexual couples (Sarantakos, 2000, p. 131).

The 2005 APA Brief does not cite this study, again leaving us to more closely examine the claim that "Not a single study has found children of lesbian or gay parents to be disadvantaged in any significant respect relative to children of heterosexual parents" (p. 15).

The Sarantakos (2000) study also includes the report that "the number of children who were labeled by their parents as gay, or identified themselves as gay, is much higher than the generally expected proportion" (p. 133). However, the study also notes areas of no significant heterosexual-homosexual differences (i.e., "Physical and emotional well-being", p. 130), consistent with the 2005 APA Brief's claims. All of these findings warranted attention in the 2005 APA Brief but were overlooked. Of most interest to us here, however, is the novel attention of Sarantakos (2000) on multiple concerns of societal importance, including drug and alcohol abuse, education (truancy), sexual activity, and criminality.

In any less-developed area of empirical inquiry it takes time, often several decades, before many of the central and most relevant questions can be adequately addressed. This seems to be the case with same-sex parenting outcomes, as several issues of societal concern were almost entirely unaddressed in the 2005 APA Brief.

\subsection{Question 6: what do we know about the long-term outcomes of children of lesbian and gay parents?}

In the preceding response to question 5 , the outcomes of intergenerational poverty, criminality, college education and/or labor force contribution, drug/alcohol abuse, suicide, early sexual activity, early childbearing, and eventual divorce as adults were mentioned. Close consideration reveals that the majority of these outcomes are not "child" outcomes. Indeed, most of these outcomes are not optimally observable until (at the earliest) mid-late adolescence or early adulthood (and in the case of divorce, not until middle adulthood). As discussed in question 5, virtually none of the peer-reviewed, same-sex parenting comparison studies addressed these outcomes. ${ }^{67}$

Additionally, of the 59 published studies cited by the APA 2005 Brief (pp. 23-45), it is difficult to find comparison studies of any kind that examine late adolescent outcomes of any kind. The few that utilize comparison groups have comparison groups of 44 or fewer. ${ }^{68}$ Let us further explore the importance of a lack of data centered on adolescents and young adults.

Table 2 identifies 15 of the hundreds of available studies on outcomes of children from intact families (as contrasted with comparison groups such as cohabiting couples and single parents). One of these studies included a data set of 35,938 children-one of "the largest. . nationally representative survey[s] of US children and their parents". ${ }^{69}$ Based on analysis of this

\footnotetext{
64 Anderssen et al. (2002, p. 343).

65 Including: intergenerational poverty, criminality, college education and/or labor force contribution, drug/alcohol abuse, suicide, sexual activity and early childbearing, and eventual divorce.

66 This study is a later, larger, and more detailed report on the earlier mentioned Sarantakos (1996) study. The sample of that study was larger than the other comparison samples in Table 1.

67 Gartrell and colleagues (1999, 2000, 2005) have commenced to do so, but in 2005 they were reporting on children who were only 10 years old (with a sample size of 74 and no heterosexual comparison group).

68 I.e. Wainwright et al. (2004).

69 Brown (2004), p. 355.
} 
nationally representative sample, Susan Brown emphasized, "The findings of this study...demonstrate the importance of separately examining children and adolescents". She then explained ${ }^{70}$ :

Although the outcomes of children (6-11 years old) in cohabiting families...are worse. . than those of children in twobiological-parent married families, much of this difference...is economic.... In contrast, regardless of economic and parental resources, the outcomes of adolescents (12-17 years old) in cohabiting families... are worse...than those...in two-biological-parent married families.

In short, in the case of cohabiting families and "two-biological-parent married families" the differences in children's outcomes increase in significance as the children grow older. The likelihood of significant differences arising between children from same-sex and married families may also increase across time-not just into adolescence but into early and middle adulthood. For example, research indicates that "[d]aughters raised outside of intact marriages are...more likely to end up young, unwed mothers than are children whose parents married and stayed married", and that "[p]arental divorce increases the odds that adult children will also divorce". ${ }^{71}$

Longitudinal studies that follow children across time and into adulthood to examine such outcomes are comparatively rare and valuable. We briefly turn to a key finding from one such study that followed children of divorce into middle adulthood. Based on a 25-year longitudinal study, Wallerstein and colleagues (2001) state:

Contrary to what we have long thought, the major impact of divorce does not occur during childhood or adolescence. Rather, it rises in adulthood as serious romantic relationships move center stage. When it comes time to choose a life mate and build a new family, the effects of divorce crescendo (p. xxix).

Wallerstein's research, like nearly all of the studies in the same-sex parenting literature, is based on a small, non-representative sample that should not be generalized or overextended. Her longitudinal work does, however, indicate that "effects [can] crescendo" in adulthood. Did any published same-sex parenting study cited by the 2005 APA Brief (pp. 23-45) track the societally significant long-term outcomes into adulthood? No. Is it possible that "the major impact" of same-sex parenting might "not occur during childhood or adolescence. . . but that it will rise] in adulthood as serious romantic relationships move center stage"? Is it also possible that "when it comes time to choose a life mate and build a new family" that the effects of same-sex parenting will similarly "crescendo" as they did in Wallerstein's study of divorce effects? In response to this or any question regarding the long-term, adult outcomes of lesbian and gay parenting we have almost no empirical basis for responding. An exception is provided by the findings from self-reports of adult "children" (18 + years of age) in Sarantakos' (2000) book-length study, but those results not encouraging. This is a single study however-a study that, like those cited by the APA Brief, lacks the statistical power and rigor of the large, random, representative samples used in marriage-based family studies (see Table 2). We now move to a final related empirical question regarding the same-sex parenting literature.

2.7. Question 7: have the studies in this area committed the type II error and prematurely concluded that heterosexual couples and gay and lesbian couples produce parental outcomes with no differences?

The Summary of Research Findings in the APA brief reads, "As is true in any area of research, questions have been raised with regard to sampling issues, statistical power, and other technical matters" (p. 5). However, neither statistical power nor the related concern of Type II error is further explained or addressed. This will be done next.

In social science research, questions are typically framed as follows: "Are we 95\% sure the two groups being compared are different?" $(p<.05)$. If our statistics seem to confirm a difference with $95 \%$ or greater confidence, then we say the two groups are "significantly different". But what if, after statistical analysis, we are only $85 \%$ sure that the two groups are different? By the rules of standard social science, we would be obligated to say we were unable to satisfactorily conclude that the two groups are different. However, a reported finding of "no statistically significant difference" (at the $p<.05$ level; 95\%-plus certainty) is a grossly inadequate basis upon which to offer the science-based claim that the groups were conclusively "the same". In research, incorrectly concluding that there is no difference between groups when there is in fact a difference is referred to as a Type II error. A Type II error is more likely when undue amounts of random variation are present in a study. Specifically, small sample size, unreliable measures, imprecise research methodology, or unaccounted for variables can all increase the likelihood of a Type II error. All one would have to do to be able to come to a conclusion of "no difference" is to conduct a study with a small sample and/or sufficient levels of random variation. These weaknesses compromise a study's "statistical power" (Cohen, 1988).

It must be re-emphasized that a conclusion of "no significant difference" means that it is unknown whether or not a difference exists on the variable(s) in question (Cohen, 1988). This conclusion does not necessarily mean that the two groups are, in fact, the same on the variable being studied, much less on all other characteristics. This point is important with samesex parenting research because Patterson $(1992,2000)$ and the 2005 APA Brief seem to draw inferences of sameness based on the observation that gay and lesbian parents and heterosexual parents appear not to be statistically different from one another based on small, non-representative samples-thereby becoming vulnerable to a classic Type II error.

\footnotetext{
70 Brown (2004), p. 364.

71 Wilcox et al. (2011), p. 11
} 
To make the APA Brief's proposition of sameness more precarious, in a review published one year after the APA Brief in the flagship APA journal, American Psychologist, Herek (2006) acknowledged that many same-sex parenting studies have "utilized small, select convenience samples and often employed unstandardized measures". ${ }^{72}$ Anderssen et al. (2002) similarly indicated in their review of same-sex parenting studies, "The samples were most often small, increasing the chance to conclude that no differences exist between groups when in fact the differences do exist. This casts doubt on the external validity of the studies". ${ }^{73}$ With these limitations noted, the 2005 APA Brief explicitly claimed that findings of non-significant differences between same-sex and heterosexual parents had been "repeatedly replicated" (p. 7, Footnote 1).

Reasons for skepticism regarding the APA Brief's claim that findings have been "repeatedly replicated" rest in Neuman's (1997) point that "the logic of replication implies that different researchers are unlikely to make the same errors". ${ }^{74}$ However, if errors (e.g., similarly biased sampling approaches employing "small, select convenience samples"75 and comparison groups) are repeated by different researchers, the logic behind replication is undermined. As has been previously detailed in the response to question 1 in this article, same-sex parenting researchers have repeatedly selected White, well-educated, middle- and upper-class lesbians to represent same-sex parents. This tendency recurred even after this bias was explicitly identified by Patterson $(1992,2000) .^{76}$ Further, repeated sampling tendencies in connection with heterosexual comparison groups (e.g., single mothers), were documented in response to Question 3 in this paper. These repeated (convenience) sampling tendencies across studies that employed different measures do not seem to constitute valid scientific replication.

An additional scientific question raised by the above information regarding "small, select convenience"77 samples is framed by Stacey and Biblarz (2001) who reveal that "many of these [comparative same-sex parenting] studies use conventional levels of significance. . .on miniscule samples, substantially increasing their likelihood of failing to reject the null hypothesis". ${ }^{78}$ Was the APA's claim that "Not a single study has found children of lesbian or gay parents to be disadvantaged..."79 based on clear scientific evidence or (perhaps) Type II errors? In response, we now turn to the APA-acknowledged but unexplained critique of low "statistical power" in these studies (p. 5).

The last three editions of the APA Publication manual (1994, 2001, 2010) have urged scholars to report effect sizes and to take statistical power into consideration when reporting their results. The APA 5th Publication manual (2001) in use at the time of APA's 2005 Brief on Lesbian and Gay Parenting stated:

Take seriously the statistical power considerations associated with your tests of hypotheses. Such considerations relate to the likelihood of correctly rejecting the tested hypotheses, given a particular alpha level, effect size, and sample size. In that regard, you should routinely provide evidence that your study has power to detect effects of substantive interest (e.g., see Cohen, 1988). You should be similarly aware of the role played by sample size in cases in which not rejecting the null hypothesis is desirable (i.e., when you wish to argue that there are no differences [between two groups])... (p. 24).

This awareness of statistical power in cases "when you wish to argue that there are no differences" bears directly on same-sex comparative research. The APA 5th Publication manual (2001) continues:

Neither of the two types of probability [alpha level or $p$ value] directly reflects the magnitude of an effect or the strength of a relationship. For the reader to fully understand the importance of your findings, it is almost always necessary to include some index of effect size or strength of relationship in your Results section (p. 25).

Let us review three statements from the APA 5th Publication Manual for emphasis:

(1) The APA urges researchers to: "Take seriously the statistical power considerations" and "routinely provide evidence" (p. 24).

(2) The APA identifies a specific concern with sample size and statistical power in connection with cases where authors "wish to argue that there are no differences" between compared groups (p. 24).

(3) The APA concludes: "It is almost always necessary to include some index of effect size or strength of relationship in your Results section” (p. 25).

The APA's first highlighted exhortation is that an author "should routinely provide evidence that your study has sufficient power. ..(e.g., see Cohen, 1988)" (p. 24). The reference cited here by the APA is the volume Statistical Power Analysis for the Behavioral Sciences (2nd ed.) by the late psychometrician Jacob Cohen, who has been credited with foundational work in statistical meta-analysis (Borenstein, 1999). In his APA-cited volume, Cohen states:

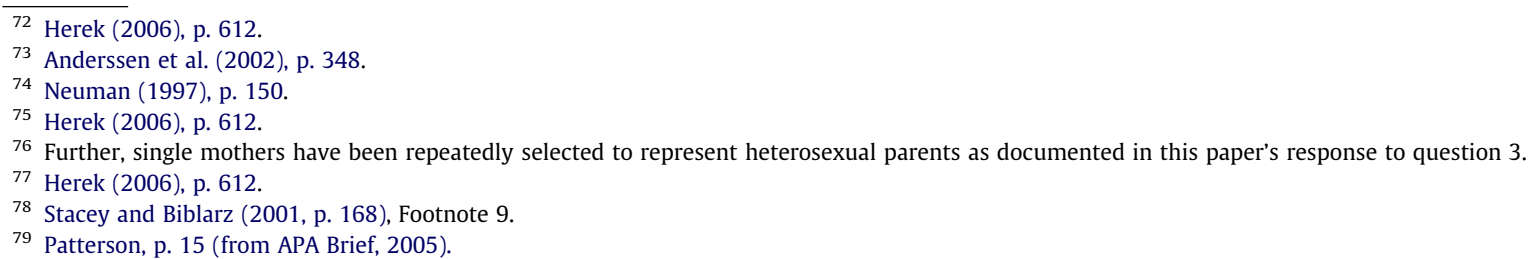


Most psychologists of whatever stripe believe that samples, even small samples, mirror the characteristics of their parent populations. In effect, they operate on the unstated premise that the law of large numbers holds for small numbers as well.... [Citing Tversky and Kahneman] "The believer in the law of small numbers has incorrect intuitions about significance level, power, and confidence intervals. Significance levels are usually computed and reported, but power and confidence levels are not. Perhaps they should be".

But as we have seen, too many of our colleagues have not responded to [this] admonition.... They do so at their peril (p. xv).

Let us contextualize "the law of small numbers" with respect to the same-sex parenting studies cited in the APA Brief. The combined non-representative sample total of all 59 same-sex parenting studies in the 2005 APA Brief (pp. 23-45) is 7800 ${ }^{80}$ (see Table 1). By comparison, Table 2 lists 15 prominent studies that contrast children's outcomes in intact, single-parent, divorced, and/or step-family forms using large probability samples and comparison groups. ${ }^{81}$ The average sample size in these studies is $9911^{82}$-a figure larger than all 59 same-sex parenting studies combined (7800).

We now turn to another question relating to Cohen's statements: How many of the published same-sex parenting studies with a heterosexual comparison group cited in APA's Brief (pp. 23-45) "provide[d] evidence" of statistical power, consistent with APA's Publication Manual and the "admonition" of Jacob Cohen who is cited in the APA manual? An examination of the studies indicates that only four of the 59 did so. ${ }^{83}$

In addition to Cohen's (1988) statement that statistical power is ignored at our own peril, he offered several tables in his volume for researchers to reference. Employing these tables, statistical experts Lerner and Nagai (2001) computed the sample sizes required for "a power level of .80, or a Type II error rate of .20, or one in five findings" (p. 102). At this power level, the minimum number of cases required to detect a small effect size ${ }^{84}$ is 393 for a T-test or ANOVA, or 780-plus for Chi-Square or Pearson Correlation Coefficient tests. ${ }^{85}$ In Table 1 of this report, the 59 published same-sex parenting studies cited in the APA Brief (pp. 23-45) are compared against these standards. A close examination indicates that not a single study, including the few that reported power, meets the standards needed to detect a small effect size. Indeed, it appears that only two of the comparison studies (Bos et al., 2003, 2004) have combined sample sizes of even half of "the minimum number of cases". ${ }^{86}$

In their book-length examination of same-sex parenting studies, Lerner and Nagai (2001) further indicate that 17 of the 22 same-sex parenting comparison studies they reviewed had been designed in such a way that the odds of failing to find a significant difference [between homo- and hetero-sexual groups] was $85 \%$ or higher. ${ }^{87}$ Indeed, only one of the 22 studies they analyzed revealed a probability of Type II error below 77 percent, and that study did find differences. ${ }^{88}$ These methodological concerns (and others) were raised and explained in Lerner and Nagai's monograph (see pp. 95-108), and in an 81-page report by Nock (2001) preceding the APA Brief. ${ }^{89}$ Nock concluded:

All of the [same-sex parenting] articles I reviewed contained at least one fatal flaw of design or execution. Not a single one was conducted according to generally accepted standards of scientific research.... [I]n my opinion, the only acceptable conclusion at this point is that the literature on this topic does not constitute a solid body of scientific evidence (Nock, 2001, pp. 39, 47).

\footnotetext{
$\overline{80}$ This figure (7800) includes same-sex parents and their children, as well as heterosexual comparison samples (1404), psychologists (388), and college students' perception reports (489).

${ }^{81}$ Table 2 lists 15 studies that contrast children's outcomes in intact families compared with other family forms using large, probability samples and comparison groups. The focal topics of these studies are not "sexual preference, gender role behavior... [and] gender identity" (Anderssen et al., 2002, p. 343), but outcomes such as "educational attainment", "labor force attachment", and "early childbearing" (McLanahan and Sandefur, 1994, pp. 20-21 ), as recommended in the earlier examination of question 5. Further, all but two of the 15 studies employ longitudinal designs, as recommended in the earlier examination of question 6 .

${ }^{82}$ This figure is the result of 148,667 divided by 15 studies.

83 These include Chan et al. (1998b), Fulcher et al. (2002), Golombok and Tasker (1996), and Tasker and Golombok (1997).

${ }^{84}$ By way of context, in a 67 study meta-analysis of the average differences in outcomes between children with "divorced and continuously married parents", Amato (2001) reported an average weighted effect size of between -0.12 and -0.22 (a -0.17 average) with an advantage in all five domains considered to children of continuously married parents (p. 360). These effect sizes of about .20, although statistically robust, would be classified by Cohen (1992) as small effect sizes. Even so, based on the data, most family scholars would agree that children whose parents remain continuously married tend to fare slightly to moderately better than when parents divorce. However, large numbers were needed to determine this "small" but important effect. Indeed, most effect sizes in social science research tend to be small. Rigorous and sound social science tends to include and account for many influential factors that each has a small but meaningful effect size. In social science, detecting a novel "large effect" from a single variable (whether it is divorce, remarriage, or same-sex parenting), is a comparatively rare occurrence. If we are to examine possible effects of same-sex parenting with scientific precision and rigor, related examinations would, like Amato's work, be designed and refined to detect "small effect" sizes.

85 Cohen (1988) proposes a "relatively high power" of .90 for cases where one is trying to "demonstrate the $r$ [difference] is trivially small" (p. 104). If the .90 power were applied, the required sample sizes would further increase. However, because none of the studies in Table 1 of the present report approach the .80 power levels, .90 calculations are unnecessary here.

${ }^{86}$ The "minimum number of cases" is 393. The two Bos et al. studies both have combined samples of 200. Four other larger samples are not comparison studies Crawford et al. (1999), Johnson and O'Connor (2002), King and Black (1999), and Morris et al. (2002).

${ }^{87}$ Lerner and Nagai (2001, p. 103).

${ }^{88}$ The single exception was Cameron and Cameron (1996) with a comparatively low probability error rate of 25\%. This study, like the Sarantakos (1996) study mentioned earlier, did report some significant differences between children of heterosexual and homosexual parents but, like Sarantakos (1996), was not addressed in the body of the 2005 APA brief but was instead moved to a footnote on p. 7. See Redding (2008) for additional discussion (p. 137).

${ }^{89}$ For similar critiques preceding the 2005 APA brief, seeNock (2001), Schumm (2004), Wardle (1997), and Williams (2000). For similar critiques post-dating the 2005 APA brief, see Byrd (2008), Schumm (2010a,b, 2011), and Redding (2008, p. 138).
} 
More specifically, Nock identified: (a) several flaws related to sampling (including biased sampling, non-probability sampling, convenience sampling, etc.); (b) poorly operationalized definitions; (c) researcher bias; (d) lack of longitudinal studies; (e) failure to report reliability; (f) low response rates; and (g) lack of statistical power (pp. 39-40). ${ }^{90}$ Although some of these flaws are briefly mentioned in the 2005 APA Summary of Research Findings on Lesbian and Gay Parenting, many of the significant concerns raised by Nock or Lerner and Nagai are not substantively addressed. ${ }^{91}$ Indeed, the Lerner and Nagai volume and the Nock report are neither mentioned nor referenced.

To restate, in connection with the APA's published urging that researchers: "Take seriously the statistical power considerations" and "routinely provide evidence", the academic reader is left at a disadvantage. ${ }^{92}$ Only a few comparison studies specifically reported statistical power at all and no comparison study approached the minimum sample size of 393 needed to find a small effect.

The author's response to question 7 has examined how comparisons have been made from a research methods standpoint. In summary, some same-sex parenting researchers have acknowledged that "miniscule samples" 93 significantly increase "the chance to conclude that no differences exist between groups when in fact the differences do exist"-thereby casting "doubt on the external validity of the studies". ${ }^{44}$ An additional concern is that the APA Brief's claim of "repeatedly replicated" findings of no significant difference rested almost entirely on studies that were published without reports of the APAurged effect sizes and statistical power analyses. ${ }^{95}$ This inconsistency seems to justify scientific skepticism, as well as the effort of more closely assessing the balance, precision, and rigor behind the conclusions posed in the 2005 APA Brief.

\section{Conclusion}

The 2005 APA Brief, near its outset, claims that "even taking into account all the questions and/or limitations that may characterize research in this area, none of the published research suggests conclusions different from that which will be summarized" (p. 5). The concluding summary later claims, "Indeed, the evidence to date suggests that home environments provided by lesbian and gay parents are as likely as those provided by heterosexual parents to support and enable children's psychosocial growth" (p. 15). ${ }^{96}$

We now return to the overarching question of this paper: Are we witnessing the emergence of a new family form that provides a context for children that is equivalent to the traditional marriage-based family? Even after an extensive reading of the same-sex parenting literature, the author cannot offer a high confidence, data-based "yes" or "no" response to this question. To restate, not one of the 59 studies referenced in the 2005 APA Brief (pp. 23-45; see Table 1) compares a large, random, representative sample of lesbian or gay parents and their children with a large, random, representative sample of married parents and their children. The available data, which are drawn primarily from small convenience samples, are insufficient to support a strong generalizable claim either way. Such a statement would not be grounded in science. To make a generalizable claim, representative, large-sample studies are needed-many of them (e.g., Table 2).

Some opponents of same-sex parenting have made "egregious overstatements" 97 disparaging gay and lesbian parents. Conversely, some same-sex parenting researchers seem to have contended for an "exceptionally clear" 98 verdict of "no difference" between same-sex and heterosexual parents since 1992. However, a closer examination leads to the conclusion that strong, generalized assertions, including those made by the APA Brief, were not empirically warranted. ${ }^{99}$ As noted by Shiller (2007) in American Psychologist, "the line between science and advocacy appears blurred" (p. 712).

The scientific conclusions in this domain will increase in validity as researchers: (a) move from small convenience samples to large representative samples; (b) increasingly examine critical societal and economic concerns that emerge during adolescence and adulthood; (c) include more diverse same-sex families (e.g., gay fathers, racial minorities, and those without middle-high socioeconomic status); (d) include intact, marriage-based heterosexual families as comparison groups; and (e)

\footnotetext{
90 Four of these seven issues are addressed in the present paper. The exceptions include researcher bias, failure to report reliability, and low response rates.

91 The 2005 APA Brief's Summary on Research Findings acknowledges criticisms of same-sex parenting research including: (a) non-representative sampling, (b) "poorly matched or no control groups", (c) "well-educated, middle class [lesbian] families", and (d) "relatively small samples" (p. 5). The respective responses to these criticisms in the APA brief are: (a) "contemporary research on children of lesbian and gay parents involves a wider array of sampling techniques than did earlier studies"; (b) "contemporary research on children of lesbian and gay parents involves a wider array of research designs (and hence control groups) than did earlier studies"; (c) "contemporary research on children of lesbian and gay parents involves a greater diversity of families than did earlier studies"; and (d) "contemporary research has benefited from such criticisms" (p. 5). The APA Brief does not challenge the validity of these research criticisms but notes that improvements are being made.

92 See Schumm (2010b) for more comprehensive, article-length treatment of these statistical issues.

93 Stacey and Biblarz (2001, p. 168)

94 Anderssen et al. (2002, p. 348).

95 Schumm (2010b).

96 The APA Brief also states that "the existing data are still limited, and any conclusions must be seen as tentative". Also, that "it should be acknowledged that research on lesbian and gay parents and their children, though no longer new, is still limited in extent" (p. 15). For some scientists, these salient points seem to be overridden by the APA Brief's conclusions.

97 This reality has been disapprovingly documented by Shiller (2007).

98 Patterson (1992).

99 In 2006, the year following APA's release of the brief on Lesbian and Gay Parenting, "former APA president Nicholas Cummings argued that there has been significant erosion" of the APA's established principle (Shiller (2007), p. 712)...that "when we speak as psychologists we speak from research evidence and clinical experience and expertise" (Cummings (2006), p. 2).
} 
constructively respond to criticisms from methodological experts. ${ }^{100}$ Specifically, it is vital that critiques regarding sample size, sampling strategy, statistical power, and effect sizes not be disregarded. Taking these steps will help produce more methodologically rigorous and scientifically informed responses to significant questions affecting families and children.

\section{References}

Akerlof, G., 1998. Men without children. Economic Journal 108, 287-309.

Amato, P., 1991. Parental absence during childhood and depression in later life. Sociological Quarterly 32, 543-556.

Amato, P., 2001. Children of divorce in the 1990s: an update of the Amoato and Keith (1991) meta-analysis. Journal of Family Psychology 15, 355-370.

Amato, P., 2005. The impact of family formation change on the cognitive, social, and emotional well-being of the next generation. The Future of Children 15 , $75-96$.

Amato, P., Booth, A., 2000. A Generation at Risk: Growing Up in an Era of Family Upheaval. Harvard University Press, Cambridge, MA.

Anderssen, N., Amlie, C., Ytteroy, E.A., 2002. Outcomes for children with lesbian or gay parents: a review of studies from 1978 to 2000 . Scandinavian Journal of Psychology 43, 335-351.

Publication manual of the American Psychological Association (forth ed.), 1994. APA, Washington, DC.

Publication manual of the American Psychological Association (fifth ed.), 2001. APA, Washington, DC.

Publication manual of the American Psychological Association (sixth ed.), 2010. APA, Washington, DC.

Aquilino, W.S., 1994. Impact of childhood family disruption on young adults' relationships with parents. Journal of Marriage and the Family 56, 295-313.

Bachman, J.G. et al, 1997. Smoking, Drinking and Drug Abuse in Young Adulthood. Erlbaum, Mahwah, NJ.

Bailey, J.M., Bobrow, D., Wolfe, M., Mikach, S., 1995. Sexual orientation of adult sons of gay fathers. Developmental Psychology 31, 124-129.

Barrett, H., Tasker, F., 2001. Growing up with a gay parent: views of 101 gay fathers on their sons' and daughters' experiences. Educational and Child Psychology 18, 62-77.

Battle, J., 1998. What beats having two parents?: educational outcomes for African-American students in single- versus dual-parent families. Journal of Black Studies 28, 783-801.

Bigner, J.J., Jacobsen, R.B., 1989a. The value of children to gay and heterosexual fathers. Journal of Homosexuality 19, 163-172.

Bigner, J.J., Jacobsen, R.B., 1989b. Parenting behaviors of homosexual and heterosexual fathers. Journal of Homosexuality 19, 173-186.

Blackmon, L., Clayton, O., Glenn, N., Malone-Colon, L., Roberts, A., 2005. The Consequences of Marriage for African Americans: A Comprehensive Literature Review. Institute for American Values, New York.

Borenstein, M., 1999. Jacob Cohen, PhD, 1923-1998. Archives of General Psychiatry 56, 581.

Bos, H.M.W., van Balen, F., van den Boom, D.C., 2003. Planned lesbian families: their desire and motivation to have children. Human Reproduction 10, 22162224.

Bos, H.M.W., van Balen, F., van den Boom, D.C., 2004. Experience of parenthood, couple relationship, social support, and child-rearing goals in planned lesbian mother families. Journal of Child Psychology and Psychiatry 45, 755-764.

Bozett, F.W., 1980. Gay fathers: how and why they disclose their homosexuality to their children. Family Relations 29, 173-179.

Brewaeys, A., Ponjaert, I., Van Hall, E.V., Golombok, S., 1997. Donor insemination: child development and family functioning in lesbian mother families. Human Reproduction 12, 1349-1359.

Brown, S.L., 2004. Family structure and child well-being: the significance of parental cohabitation. Journal of Marriage and Family 66, 351-367.

Byrd, A.D., 2008. Conjugal marriage fosters healthy human and societal development. In: Wardle, L. (Ed.), What's the Harm? Does Legalizing Same-Sex Marriage Really Harm Individuals, Families or Society? University Press, Lanham, MD, pp. 3-26.

Cameron, P., Cameron, K., 1996. Homosexual parents. Adolescence 31, 757-776.

Chan, R.W., Brooks, R.C., Raboy, B., Patterson, C.J., 1998a. Division of labor among lesbian and heterosexual parents: associations with children's adjustment. Journal of Family Psychology 12, 402-419.

Chan, R.W., Raboy, B., Patterson, C.J., 1998b. Psychosocial adjustment among children conceived via donor insemination by lesbian and heterosexual mothers. Child Development 69, 443-457.

Chase-Lansdale, P.L., Cherlin, A.J., Kiernan, K.K., 1995. The long-term effects of parental divorce on the mental health of young adults: a developmental perspective. Child Development 66, 1614-1634.

Cherlin, A.J. et al, 1995. Parental divorce in childhood and demographic outcomes in young adulthood. Demography 32, 299-318.

Cherlin, A.J., Chase-Lansdale, P.L., McRae, C., 1998. Effects of parental divorce on mental health throughout the life course. American Sociological Review 63, 239-249.

Ciano-Boyce, C., Shelley-Sireci, L., 2002. Who is mommy tonight? Lesbian parenting issues. Journal of Homosexuality 43, 1-13.

Cohen, J., 1988. Statistical Power Analysis for the Behavioral Sciences, second ed. Erlbaum, Hillsdale, NJ.

Cohen, J., 1992. A power primer. Psychological Bulletin 112, 155-159.

Crawford, I., McLeod, A., Zamboni, B.D., Jordan, M.B., 1999. Psychologists' attitudes toward gay and lesbian parenting. Professional Psychology: Research and Practice 30, 394-401.

Cummings, N.A., 2006. The APA and psychology need reform. Paper presented at the annual convention of the American Psychological Association (August 12). New Orleans, LA.

Cutler, D.M. et al., 2000. Explaining the rise in youth suicide. Working Paper 7713. National Bureau of Economic Research, Cambridge.

Demo, D.H., Cox, M.J., 2000. Families with young children: a review of research in the 1990s. Journal of Marriage and the Family 62, 876-895.

Ellis, B.J. et al, 2003. Does father absence place daughters at special risk for early sexual activity and teenage pregnancy? Child Development $74,801-821$.

Flaks, D., Ficher, I., Masterpasqua, F., Joseph, G., 1995. Lesbians choosing motherhood: a comparative study of lesbian and heterosexual parents and their children. Developmental Psychology 31, 104-114.

Flewelling, R.L., Bauman, K.E., 1990. Family structure as a predictor of initial substance use and sexual intercourse in early adolescence. Journal of Marriage and the Family 52, 171-181.

Fulcher, M., Chan, R.W., Raboy, B., Patterson, C.J., 2002. Contact with grandparents among children conceived via donor insemination by lesbian and heterosexual mothers. Parenting: Science and Practice 2, 61-76.

Gartrell, N., Hamilton, J., Banks, A., Mosbacher, D., Reed, N., Sparks, C.H., Bishop, H., 1996. The national lesbian family study: 1. Interviews with prospective mothers. American Journal of Orthopsychiatry 66, 272-281.

Gartrell, N., Banks, A., Hamilton, J., Reed, N., Bishop, H., Rodas, C., 1999. The national lesbian family study: II. Interviews with mothers of toddlers. American Journal of Orthopsychiatry 69, 362-369.

Gartrell, N., Banks, A., Reed, N., Hamilton, J., Rodas, C., Deck, A., 2000. The national lesbian family study: III. Interviews with mothers of five-year olds. American Journal of Orthopsychiatry 70, 542-548.

Gartrell, N., Deck, A., Rodas, C., Peyser, H., Banks, A., 2005. The national lesbian family study: 4. Interviews with the 10-year old children. American Journal of Orthopsychiatry $75,518-524$.

Gaudino, J.A. et al, 1999. No fathers' names: a risk factor for infant mortality in the state of Georgia. Social Science and Medicine 48, 253-265.

$\overline{100}$ At least one such study (Rosenfeld, 2010) has emerged in the years since the 2005 APA brief was issued. This study features a very large sample but has also received criticism (Schumm, 2011). 
Gershon, T.D., Tschann, J.M., Jemerin, J.M., 1999. Stigmatization, self-esteem, and coping among the adolescent children of lesbian mothers. Journal of Adolescent Health 24, 437-445.

Glenn, N.D., 1989. What we know, what we say we know: discrepancies between warranted and stated conclusions in the social sciences. In: Eulau, H. (Ed.), Crossroads of Social Science. The ICPSR 25th Anniversary Volume. Agathon Press, New York, pp. 119-140.

Glenn, N.D., 1997. A reconsideration of the effect of no-fault divorce on divorce rates. Journal of Marriage and the Family 59, 1023-1025.

Golombok, S., Rust, J., 1993. The pre-school activities inventory: a standardized assessment of gender role in children. Psychological Assessment 5, 131-136.

Golombok, S., Tasker, F., 1996. Do parents influence the sexual orientation of their children? Findings from a longitudinal study of lesbian families. Developmental Psychology 32, 3-11.

Golombok, S., Spencer, A., Rutter, M., 1983. Children in lesbian and single-parent households: psychosexual and psychiatric appraisal. Journal of Child Psychology and Psychiatry 24, 551-572.

Golombok, S., Tasker, F., Murray, C., 1997. Children raised in fatherless families from infancy: family relationships and the socioemotional development of children of lesbian and single heterosexual mothers. Journal of Child Psychology and Psychiatry 38, $783-791$.

Golombok, S., Perry, B., Burston, A., Murray, C., Mooney-Somers, J., Stevens, M., Golding, J., 2003. Children with lesbian parents: a community study. Developmental Psychology 39, 20-33.

Green, R., 1978. Sexual identity of 37 children raised by homosexual or transsexual parents. American Journal of Psychiatry $135,692-697$.

Green, R., Mandel, J.B., Hotvedt, M.E., Gray, J., Smith, L., 1986. Lesbian mothers and their children: a comparison with solo parent heterosexual mothers and their children. Archives of Sexual Behavior 7, 175-181.

Harper, C., McLanahan, S., 2004. Father absence and youth incarceration. Journal of Research on Adolescence 14, 369-397.

Harris, M.B., Turner, P.H., 1986. Gay and lesbian parents. Journal of Homosexuality 12, 101-113.

Heiss, J., 1996. Effects of African American family structure on school attitude and performance. Social Problems 43, $246-267$.

Herek, G.M., 2006. Legal recognition of same-sex relationships in the United States: a social science perspective. American Psychologist 61, 607-621.

Hetherington, M., Kelly, J., 2002. For Better or for Worse: Divorce Reconsidered. Norton, New York.

Hoeffer, B., 1981. Children's acquisition of sex-role behavior in lesbian mother families. American Journal of Orthopsychiatry 5, 536-544.

Horwitz, A.V., White, H.R., Howell-White, S., 1996. Becoming married and mental health: a longitudinal study of a cohort of young adults. Journal of Marriage and the Family 58, 895-907.

Huggins, S.L., 1989. A comparative study of self-esteem of adolescent children of divorced lesbian mothers and divorced heterosexual mothers. Journal of Homosexuality 18, 123-135.

Jekielek, S., 1998. Parental conflict, marital disruption, and children's emotional well-being. Social Forces 76, 905-936.

Johnson, S.M., O'Connor, E., 2002. The Gay Baby Boom: The Psychology of Gay Parenthood. NYU Press, New York.

Johnson, R.A. et al, 1996. The Relationship Between Family Structure and Adolescent Substance Abuse. US Dept. of Health and Human Services, Rockville, MD.

Kamark, E.C., Galston, W.A., 1990. Putting Children First: A Progressive Family Policy for the 1990s. Progressive Policy Institute, Washington, DC.

King, B.R., Black, K.N., 1999. College students' perceptual stigmatization of the children of lesbian mothers. American Journal of Orthopsychiatry 69, 220227.

Kirkpatrick, M., Smith, C., Roy, R., 1981. Lesbian mothers and their children: a comparative survey. American Journal of Orthopsychiatry 51, 545-551.

Koepke, L., Hare, J., Moran, P., 1992. Relationship quality in a sample of lesbian couples with children and child-free lesbian couples. Family Relations 41, $224-229$

Kuhn, T.S., 1970/1996. The Structure of Scientific Revolutions, third ed. University of Chicago Press, Chicago

Kweskin, S.L., Cook, A.S., 1982. Heterosexual and homosexual mothers' self-described sex-role behavior and ideal sex-role behavior in children. Sex Roles 8, $967-975$.

Lansford, J.E., 2009. Parental divorce and children's adjustment. Perspectives on Psychological Science 4, $140-152$.

Lerner, R., Nagai, A., 2001. No Basis: What the Studies Don't Tell us About Same-Sex Parenting. Marriage Law Project, Washington, DC.

Lewis, K.G., 1980. Children of lesbians: Their point of view. Social Work, 198-203.

Lichter, D.T., Graefe, D.R., Brown, J.B., 2003. Is marriage a panacea? Union formation among economically disadvantaged unwed mothers. Social Problems $50,60-86$.

Lott-Whitehead, L., Tully, C.T., 1993. The family lives of lesbian mothers. Smith College Studies in Social Work 63, 265-280.

Lyons, T.A., 1983. Lesbian mother's custody fears. Women \& Therapy 2, 231-240.

MacCallum, F., Golombok, S., 2004. Children raised in fatherless families from infancy: a follow-up of children of lesbian and single heterosexual mothers at early adolescence. Journal of Child Psychology and Psychiatry 45, 1407-1419.

Manning, W.D., Lamb, K.A., 2003. Adolescent well-being in cohabiting, married, and single-parent families. Journal of Marriage and Family 65, 876-893.

Margolin, L., 1992. Child abuse by mothers' boyfriends: why the overrepresentation? Child Abuse and Neglect 16, 541-551.

McLanahan, S., Sandefur, G., 1994. Growing Up with a Single Parent: What Hurts, What Helps. Harvard University Press, Cambridge, MA.

McLeod, A.C., Crawford, I., Zecheister, J., 1999. Heterosexual Undergraduates' Attitudes Toward Gay Fathers and their Children. Journal of Psychology and Human Sexuality 11, 43-62.

Miller, B., 1979. Gay fathers and their children. Family Coordinator 28, 544-552.

Miller, J.A., Jacobsen, R.B., Bigner, J.J., 1981. The child's home environment for lesbian versus heterosexual mothers: a neglected area of research. Journal of Homosexuality 7, 49-56.

Mitchell, K.S., Booth, A., King, V., 2009. Adolescents with nonresident fathers: are daughters more disadvantaged than sons? Journal of Marriage and Family $71,650-662$

Moore, M.R., 2008. Gendered power relations among women: a study of household decision making in Black, lesbian step families. American Sociological Review 73, 335-356.

Moore, K.A., Jekielek, S.M., Emig, C.E., 2002. Marriage From a Child's Perspective: How Does Family Structure Affect Children, and What Can We Do About It? Child Trends Research Brief, Washington, DC.

Morris, J.F., Balsam, K.F., Rothblum, E.D., 2002. Lesbian and bisexual mothers and non-mothers: demographics and the coming out process. Journal of Family Psychology 16, 144-156.

Mucklow, B.M., Phelan, G.K., 1979. Lesbian and traditional mothers' responses to adult responses to child behavior and self concept. Psychological Reports $44,880-882$.

Neuman, W.L., 1997. Social Research Methods, third ed. Allyn \& Bacon, Boston.

Nock, S.L., 1998. Marriage in Men's Lives. Oxford University Press, New York.

Nock, S., 2001. The Affidavit of Steven Nock, Halpern v. Attorney General of Canada, No. 684/00 (Ont. Sup. Ct. of Justice).

O'Connell, A., 1993. Voices from the heart: the developmental impact of a mother's lesbianism on her adolescent children. Smith College Studies in Social Work 63, 281-299.

Oliver, M.L., Shapiro, T.M., 1997. Black Wealth/White Wealth. Routledge, New York.

Page, M.E., Stevens, A.H., 2005. Understanding racial differences in the economic costs of growing up in a single-parent family. Demography $42,75-90$. Pagelow, M.D., 1980. Heterosexual and lesbian single mothers: a comparison of problems, coping, and solutions. Journal of Homosexuality 5, $198-204$.

Patterson, C.J., 1992. Children of lesbian and gay parents. Child Development 63, 1025-1042.

Patterson, C.J., 1994. Children of the lesbian baby boom: Behavioral adjustment, self-concepts, and sex-role identity. In: Greene, B., Herek, G. (Eds.), Contemporary Perspectives on Lesbian and Gay Psychology: Theory, Research, and Application. Sage, Beverly Hills, CA, pp. $156-175$.

Patterson, C.J., 1995. Families of the lesbian baby boom: parents' division of labor and children's adjustment. Developmental Psychology $31,115-123$. 
Patterson, C.J., 2000. Family relationships of lesbians and gay men. Journal of Marriage and the Family 62, $1052-1069$.

Patterson, C.J., 2001. Families of the lesbian baby boom: maternal mental health and child adjustment. Journal of Gay and Lesbian Psychotherapy 4 (3/4), 91-107.

Patterson, C.J., 2005. Lesbian and gay parents and their children: summary of research findings. Lesbian and Gay Parenting: American Psychological Association, pp. 5-22.

Patterson, C.J., Hurst, S., Mason, C., 1998. Families of the lesbian baby boom: children's contacts with grandparents and other adults. American Journal of Orthopsychiatry 68, 390-399.

Phillips, C.P., Asbury, C.A., 1993. Parental divorce/separation and the motivational characteristics and educational aspirations of African American university students. The Journal of Negro Education 62, 204-210.

Rand, C., Graham, D.L.R., Rawlings, E.I., 1982. Psychological health and factors the court seeks to control in lesbian mother custody trials. Journal of Homosexuality 8, 27-39.

Rank, M.R., Hirschl, T.A., 1999. The economic risk of childhood in America: estimating the probability of poverty across the formative years. Journal of Marriage and the Family 61, 1058-1067.

Redding, R., 2008. It's really about sex: same-sex marriage, lesbigay parenting, and the psychology of disgust. Duke Journal of Gender Law \& Policy 15 , $128-$ 193.

Roese, N.J., Olson, J.M., 2007. Better, stronger, faster self-serving judgment, affect regulation, and the optimal vigilance hypothesis. Perspectives on Psychological Science 2, 124-141.

Rosenfeld, M.J., 2010. Nontraditional families and childhood progress through school. Demography 47, 755-775.

Sarantakos, S., 1996. Children in three contexts: family, education, and social development. Children Australia 21, 23-31.

Sarantakos, S., 2000. Same-Sex Couples. Harvard Press, Sydney.

Sarantakos, S., 2005. Social Research, third ed. Palgrave Macmillan.

Sarantakos, S., 2007a. Data analysis, vol. 4. Sage, Thousand Oaks, CA

Sarantakos, S., 2007b. Tool Kit for Quantitative Data Analysis. Palgrave Macmillan.

Schumm, W.R., 2004. What was really learned from Tasker and Golombok's (1995) study of lesbian and single parent mothers? Psychological Reports 94, $422-424$.

Schumm, W.R., 2010a. Comparative relationship stability of lesbian mother and heterosexual mother families: a review of evidence. Marriage \& Family Review 46, 499-509.

Schumm, W.R., 2010b. Statistical requirements for properly investigating a null hypothesis. Psychological Reports 107, $953-971$.

Schumm, W.R., 2011. Child outcomes associated with lesbian parenting: Comments on Biblarz and Stacy's 2010 report. Journal of Human Sexuality 3, 3580 .

Schwandt, T., 2001. Dictionary of Qualitative Inquiry. Sage, Thousand Oaks, CA.

Shiller, V.M., 2007. Science and advocacy issues in research on children of gay and lesbian parents. American Psychologist 62, 712-713.

Siegel, C. et al, 1996. Mortality from intentional and unintentional injury among infants of young mothers in Colorado, 1982-1992. Archives of Pediatric and Adolescent Medicine 150, 1077-1083.

Siegenthaler, A.L., Bigner, J.J., 2000. The value of children to lesbian and non-lesbian mothers. Journal of Homosexuality 39, 73-91.

Simon, R.W., 2002. Revisiting the relationships among gender, marital status, and mental health. American Journal of Sociology 107, 1065-1096.

Stacey, J., Biblarz, T.J., 2001. (How) does the sexual orientation of parents matter? American Sociological Review 66, $159-183$.

Steckel, A., 1985. Separation-Individuation in Children of Lesbian and Heterosexual Couples. Unpublished doctoral dissertation, The Wright Institute Graduate School, Berkeley, CA.

Steckel, A., 1987. Psychosocial development of children in lesbian mothers. In: Bozett, F.W. (Ed.), Gay and Lesbian Parents. Praeger, New York, pp. 75-85.

Strasser, M., 2008. The alleged harms of recognizing same-sex marriage. In: Wardle, L. (Ed.), What's the Harm? Does Legalizing Same-Sex Marriage Really Harm Individuals, Families or Society? University Press, Lanham, MD, pp. 27-46.

Sullivan, M., 1996. Rozzie and Harriett? Gender and family parents of lesbian coparents. Gender and Society 10, 747-767.

Tasker, F.L., Golombok, S., 1995. Adults raised as children in lesbian families. American Journal of Orthopsychiatry 65, $203-215$.

Tasker, F.L., Golombok, S., 1997. Growing Up in a Lesbian Family: Effects on Child Development. Guilford, New York.

Tasker, F.L., Golombok, S., 1998. The role of co-mothers in planned lesbian-led families. Journal of Lesbian Studies 2, 49-68.

Teachman, J.R. et al, 1998. Sibling resemblance in behavioral and cognitive outcomes: the role of father presence. Journal of Marriage and the Family 60, 835-848.

Vanfraussen, K., Ponjaert-Kristoffersen, I., Brewaeys, A., 2003. Family functioning in lesbian families created by donor insemination. American Journal of Orthopsychiatry 73, 78-90.

Wainright, J.L., Russell, S.T., Patterson, C.J., 2004. Psychosocial adjustment, school outcomes, and romantic relationships of adolescents with same-sex parents. Child Development 75, 1886-1898.

Waite, L., 1995. Does marriage matter? Demography 32, 483-507.

Waite, L., Gallagher, M., 2000. The Case for Marriage: Why Married People are Happier, Healthier, and Better off Financially. Doubleday, New York.

Wallerstein, J., Lewis, J.M., Blakeslee, S., 2001. The Unexpected Legacy of Divorce. Hyperion, New York.

Wardle, L.D., 1997. The potential impact of homosexual parenting on children. University of Illinois Law Review 1997, $833-919$.

Weitoft, G.R. et al, 2003. Mortality, severe morbidity, and injury in children living with single parents in Sweden: a population-based study. The Lancet 361, 289-295.

Wilcox, W.B. et al, 2005. Why Marriage Matters, second ed. Institute for American Values, New York.

Wilcox, W.B. et al, 2011. Why Marriage Matters, third ed. Institute for American Values, New York.

Williams, R.N., 2000. A critique of the research on same-sex parenting. In: Dollahite, D.C. (Ed.), Strengthening Our Families. Bookcraft, Salt Lake City, UT, pp. 325-355.

Wolfinger, N.H., 2005. Understanding the Divorce Cycle: The Children of Divorce in their Own Marriages. Cambridge University Press, New York.

Wright, J.M., 1998. Lesbian Stepfamilies: An Ethnography of Love. Harrington Park, New York. 